\title{
Analysis of Healthy and Halal Food Consumption on Muslim Students at Elementary School in Pekanbaru
}

\author{
Y Kurniawati ${ }^{1}$, R Rohani ${ }^{2}$, S Hasri ${ }^{3}$ \\ Universitas Islam Negeri (UIN) Sulatan Syarif Kasim, Riau, Pekanbaru-Indonesia ${ }^{1,2,3}$ \\ \{yenni.kurniawati@uin-suska.ac.id'1 , rohani@uin-suska.ac.id², salfen.hasri@uin-suska.ac.id ${ }^{3}$ \}
}

\begin{abstract}
Culture, social, personality, psychology, and religion are the main factors in choosing food for an individual. However, unfortunately for religion and health factor still does not become the reason for selecting the food for most of muslim students at elementary school (SD). This research was conducted to analyze the pattern of healthy and halal food consumption by muslim students at elementary school by using mixed method with embedded design. The results show a poor condition. About $57 \%$ students have tendency to choose unhealthy food. For the reason of choice, the effect of culture $54 \%$, personality reason $48 \%$, and social-economy reason $71 \%$. Meanwhile, $59 \%$ food that they consume are doubtful whether it is halal or not. Halal label does not have significant effect towards the choice of food for muslim students of elementary school in Pekanbaru. Therefore, the education on halal food for muslim students at elementary school is pivotal. The family, students, teachers, and school members must pay attention on this case and avoid the damage on individuals of the future generation.
\end{abstract}

Keywords: Food Consumption, Elementary School Students, Healthy, Halal

\section{Introduction}

For students at elementary school, healthy and halal food are important components which support their development, because of their second phase of human brain intelligence after toddler age [1], [2]. Kids in this age are also the group of age which are susceptible to nutrients and vulnerable to disease [2]. Unfortunately, this range of age is a time when the kids often consume food out of their parents' control, especially when they are at school. This timeis become the first time for them to choose their own food without parents' supervision, and the environment where they grow up. Therefore, the effect of school environment and the quality of food sold at the school becomes an important factor to determine the quality of kids' nutrition, health, and these all affect their intelligence.

Religion, personality, culture, social economy, and students' psychological factor are some important factors which influence type, habit, and consumption pattern of elementary school students [2]-[7]. The chance of unhealthy and non halal food consumption become the vulnerable things they choose because the culture of having breakfast and bring their own food from home still do not fully become the culture of kids school age in Indonesia [3]. The price of food which is relatively cheap, directly or indirectly, becomes an important factor in influencing the quality of food sold at the school canteen or the merchants selling around the school environment [8]. The selection and consumption of food at school becomes important to be recognized by parents, school, and the environment surrounding the school. 


\section{Food}

Food is the basic needs of all human in the world. In general food is needed to stay alive. However for modern human, food is more than just to produce energy to survive life [9]. Food is required to improve the quality of health, intelligence, even for some case food becomes the identity of a culture or a family, opportunity of business deal, and social status [9],[10],[11]. The needs of food nutrients consumed by human are different from one to another in accordance with their age, work, and daily activity. For students who are still at school, the food that they consume at school extremely influence the needs of their nutrients and health.

Healthy and halal food truly support kids growth and development. Sufficient nutrients will increase their intelligence and endurance. Meanwhile the food containing dangerous materials can poison them or causing certain illness. Non-halal food can cause disorder of physical health and the difficulty of kids in accepting the teaching of Islam. Unfortunately, the food sold around elementary school environment is one with low quality, low nutrient, contents dangerous addictive substance, and has probality of non halal food.It become serious threat for the future generation[12].

\section{Halal Food}

The word 'halal' comes from Arabic which literally means 'permissible', and in technical meaning, 'halal' refers to all things and activities allowed by shariah [5]. The basic concept comes from Al-Qur'an and Hadist, in which there are 19 verses from 17 surah in Al-Qur'an talking about halal, and some hadist. In Qur'an, Al-Baqarah verse 173 and Al Maidah verse 3, Allah forbids carcass, blood, pork, and animals slaughtered without saying the name of Allah. Beside that, in Qur'an Surah Al-Maidah verse 9 alcohol is also forbidden for muslims to drink [13].

In the regulation of Indonesia, halal food categorized by Indonesian Ulama Council (MUI) are the food that: 1) do not contain pig and its derivative, 2) do not contain khamr and its derivative, 3) all meat must comes from animals slaughtered according to Islamic procedures, (4) do not contain other ingredients that are banned or classified as unclean (5) of all storage, sale, processing, management, and public means of transportation for the halal products cannot be used for pigs or other illicit goods. Use of facilities for halal and non-halal alternates are not allowed [5]. In advance countries even with non muslims majority, food with halal certificate is important for muslim population [14]. It means, halal food are not only the food that contains allowed materials, but also in the process of making which can make it not halal if not suitable with Islam. Therefore, we need to be careful in consuming the food with probability of mixed with forbidden materials in it.

The objective of this research were to analyze the consumption pattern of elementary school students in Pekanbaru and surround it, which is famous of its consumptive behavior. The results of this research are expected to be the basic of policy taken at school, education for parents, and the merchant around the school and in synergy tries to improve the quality of food for students, either in the case of health quality or its halal for food/snacks for elementary school students. How far they consider the aspect of health and halal of food they consume, and what factor which influences the selection of healthy and halal food for elementary school students in Pekanbaru? The analysis on healthy and halal food for Muslim students is expected to be initial effort to ensure what steps can be done to improve the quality of food consumed by students. 


\section{Method}

This research was conducted by using mixed method with embedded design, in which the data were taken quantitatively and qualitatively embedded in it. Quantitative data were the main data of this research, and qualitative data became the supporting data for the quantitative ones in order to explain data obtained as seen in Figure 1. Samples of this research were 178 students of grade V and VI selected randomly from 5 schools spread in Pekanbaru, 10 teachers, 10 parents, and 10 merchants selling their food at school canteen. Data were taken by using research instruments such as questionnaires, observation, and interview. Data of students' questionnaires were supported by daily observation for 30 days more or less, to ensure the suitability of questionnaires filled by the students and the reality existed. Observation and interview were done towards some merchants at school canteen and around it to know type of food they sell, and is there any possibility of containing dangerous addictive substance and or non halal food materials. The interview was also conducted towards teachers and students' parents to know in general the pattern/habits of eating done by the students at school and at home. Data were analyzed through calculation of the average of questionnaire results by the students to know the category of food they consume either at home or at school.

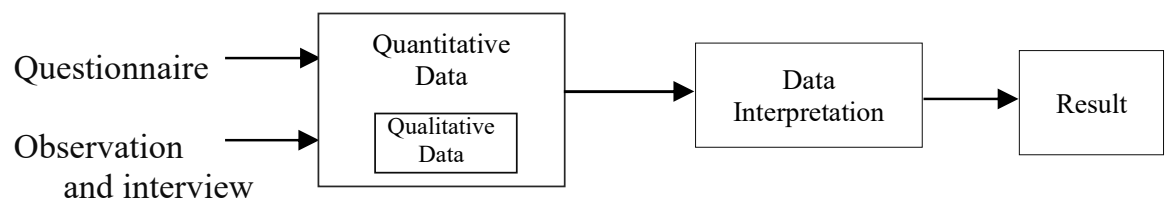

Fig. 1 Research Design

\section{Results and Discussion}

The results related to the quantity of food which is frequently consumed by elementary school students at school and around the school in Pekanbaru is shown in Table 1.

Tabel 1. Percentage of Unhealthy Food Consumption Choices for Elementary Students in Schools

\begin{tabular}{llc}
\hline No & Food & Percentage of Students \\
\hline $\mathbf{1}$ & Candy & $63 \%$ \\
$\mathbf{2}$ & Chocolate & $52 \%$ \\
$\mathbf{3}$ & Sweet Ice & $60 \%$ \\
$\mathbf{4}$ & Fried Food & $53 \%$ \\
$\mathbf{5}$ & Instant Noodles & $56 \%$ \\
$\mathbf{6}$ & Cake/Snack with high-MSG & $64 \%$ \\
$\mathbf{7}$ & Cake/Snack with cyclamate & $49 \%$ \\
$\mathbf{8}$ & Cake/Snack with high-textile dye & $58 \%$ \\
& Average & $\mathbf{5 7 \%}$ \\
\hline
\end{tabular}

Unhealthy food are the highest number of much food being observed on the students and the interview with the merchants. These eight kinds of food are the top highest loved by around a half of total number of elementary school students who became the samples of this 
research. The type of food are classified based on its danger towards health in which these top 8 are unhealthy food if consumed.

From the questionnaires recapitulated in Table 1, it shows that unhealthy food are loved by more than $50 \%$ of the average respondents, with candies and snacks containing high MSG becomes the food they love the most. Kids choose them based on the delicious taste, interesting package, and reasonable price [15]. This is certainly worrying, considering these 8 food loved by muslim students at elementary school have danger substances for their own health.

This unhealthy food preference can be extremely dangerous for students' health [16]. Sweet food such as candies and chocolates can cause damage on the teeth, ice coming from raw water can disturb the digestion, let alone with the addition of too much cyclamate that can trigger cancer [17]. Fried food with oil which is repeatedly used containing carcinogen substance [18] that can trigger cancer, excessive intant noodles can increse the risk of obesity, dyslipidemia and hypertension [19], let alone with mono sodium glutamat (MSG) which can damage the brain [20]. Beside that, cakes opened free without any package invites flies, dust, and dirt can stick on the food and cause disease. While food and drink with textile dyes (added to attract kids as buyers), if accumulated this can damage the kidney [21].

From the observation towards the students and the interview with the merchants obtained data that there are three kinds of food that their halal is extremely doubtful. They are meatball (soup meatballs, skewer meatballs, and grilled meatballs), somay and sausage. There is possibility that other food are not halal, however this research focuses on the main ingredient. The results of this research show the average higher consumption choice (Table 2).

Table 2. Percentage of Selection of Doubtful Halal Food Consumption of Elementary School Students at Schools

\begin{tabular}{llc}
\hline No & Doubtful Halal Food & Percentage of Students \\
\hline $\mathbf{1}$ & Somay & $63 \%$ \\
$\mathbf{2}$ & Meatball & $66 \%$ \\
$\mathbf{3}$ & Sosis & $55 \%$ \\
& Average & $\mathbf{5 9 \%}$ \\
\hline
\end{tabular}

Meatballs are the percentage of food that are loved the most by the students. Whereas, the results of the interview with the merchants, the school still cannot ensure the halal of the meat which becomes the main materials of the meatballs. Some of them say that the meatballs that they sell come from the market with unclear materials, some others make their own meatballs from meat which they grind at public meat mill which does not separate the grinding of beef and pork.

Siomay also has relatively high percentage consumed by muslim students at elementary school. Even though siomay commonly contains raw materials such as fish, but there is possibility that the basic materials such as chicken and pork. The phenomenon of 'cu-nyuk' somay with basic material is pork becomes worry. Tiren chicken also becomes the threat for the halal of somay. The results of the interview with the merchants show that somay that they sell, most of them come from agen of somay seller of a cart.

More than a half of respondents of Muslim students at elementary school love sausage, in which the sausage that they consume is unknown for its basic materials, because $70 \%$ of merchants buy the wrapped susage without halal logo. Sausage with main materials is meat, or mixed of meat [22] which can come from pork, or beef polluted by pork, dead chicken meat, or rabbit meat that are not slaughtered according to shariah. 
Moreover, the research results show that halal label has no significant effect towards the choice of food for muslim elementary school students in Pekanbaru. This is signed by the results of questionnaires which ask them to choose the food; between food with halal logo and food with no halal logo, and the results show that they do not care. Therefore, halal logo from MUI is also need to be introduced early to the students because the entrance of food from overseas with non halal category needs their caution. Halal logo should be the important preference for kids in buying food [23].

To minimize the consumption of unhealthy and non halal food, one of the parenting efforts is nurturing the habit of taking food from home, supported with education and habits from school. This research also tries to know the interest of students' snacks at school, their habit of having breakfast or bring the food from home to school, as shown in Figure 2.

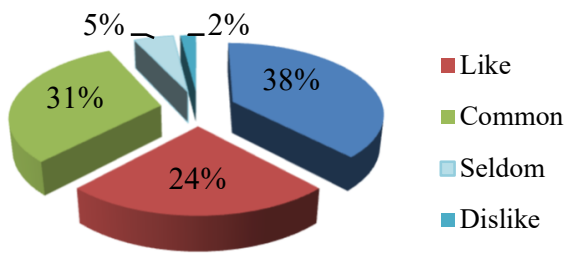

Fig. 2 Food Frequency of Muslim Student in Elementary School Eating at School

There are about $38 \%$ of students that are not too dependant on the snacks at school. In other words, they can have breakfast first at home and bring their own food from home, and $62 \%$ of students also frequently consume snacks at school. It means, even though not dominant, more than one third students have habit of consuming good food which is expected to be as certain color for their friends, with the assistance of the parents and school. For the students who dominantly eat food bought at school, there should be an effort of education to the merchants intensively and also given sufficient supervision. Therefore, it is better to see the preference of the students in preparing the food at school as shown in Figure 3.

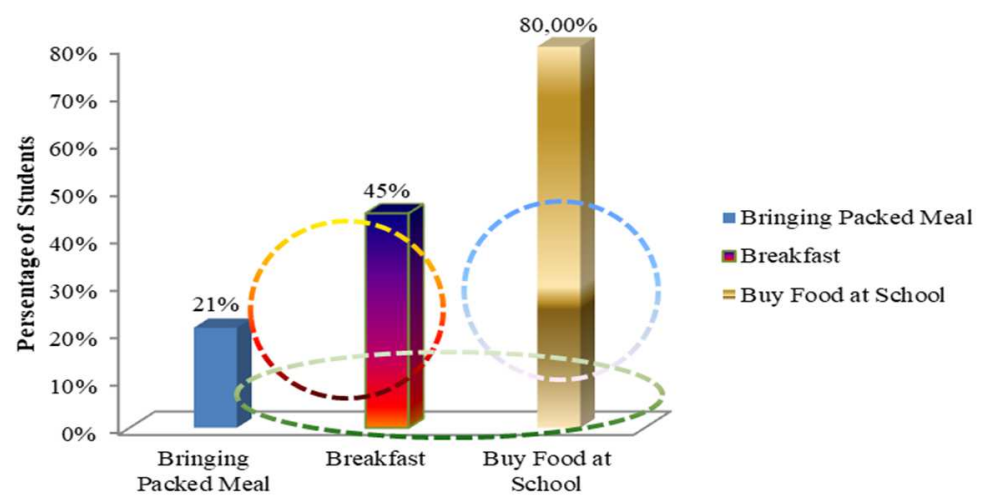

Fig. 3 The Habits of Muslim Student in Elementary School in Preparing Meals

The Figure 1 means that there are students who bring food from home and no snacks. There are also students who have breakfast and snacks at home $(31 \%)$, and without snacks $(8 \%)$, no breakfast and no snacks $(53 \%)$, bring food from home with snacks $(9 \%)$, without 
snacks $(6 \%)$, having breakfast and bring food from home $(2 \%)$, breakfast, bring food from home, and still buy snacks (4\%). This shows that the students are still vulnerable to consuming food at school even though they had their breakfast at home and bring their own food from home, though the number is relatively small. This fact proves again the need of school and parents' seriousness in educating the students to know, understand, and do consumption on halal and healthy food.

It can be seen from the review of healthy and halal food, actually the students who have breakfast at home and bring meals from home to school. This research also digs the type of breakfast and the type of meals loved by muslim students. The results show that side dishes menu loved by the majority of the students are healthy food, although vegetable menu still need to be improved and intant noodles need to be decreased either its intensity or its quantity.

Table 3. Meals Package Content of Muslim Elementary School Students

\begin{tabular}{llc}
\hline No & Food & $\begin{array}{c}\text { Percentage of Students } \\
\text { Who Often Consumed }\end{array}$ \\
\hline $\mathbf{1}$ & Vegetables & $55 \%$ \\
$\mathbf{2}$ & Milk & $63 \%$ \\
$\mathbf{3}$ & Fish & $60 \%$ \\
$\mathbf{4}$ & Chicken & $68 \%$ \\
$\mathbf{5}$ & Meat & $55 \%$ \\
$\mathbf{6}$ & Instant Noodle & $55 \%$ \\
$\mathbf{7}$ & Nugget & $34 \%$ \\
\hline
\end{tabular}

Even though health quality and its halal still cannot be determined, some researches have successfully proven the worse quality of food sold by the merchants around elementary school compared to the food prepared by their parents at home. However, to guarantee the quality of food from home and the food sold at school, and in order to conduct education towards the parents, teachers, and merchants around the school, it is important to recognize the factors which determine the choice of food consumed by students at school.

Table 4. Factors of Food Preference of Elementary School Students in Schools

\begin{tabular}{llc}
\hline No & Factors & Percentage \\
\hline $\mathbf{1}$ & Culture & $54 \%$ \\
$\mathbf{2}$ & Social Economy & $71 \%$ \\
$\mathbf{3}$ & Psychology/Personal & $48 \%$ \\
$\mathbf{4}$ & Healthy & $26 \%$ \\
$\mathbf{5}$ & Religion & $38 \%$ \\
\hline
\end{tabular}

Social-economy factor is the factor which has the biggest impact on students' food preference at elementary school, followed by cultural factor, and psychology factor of students' personality. The most unfortunate thing is religion and health factor are not the main factor for the students. Therefore, healthy and halal food education is very important for the students. The students' family, teachers, and all school members must follow and give supports towards the selection of healthy food, in line with religion rules, to avoid the damage on individuals of future generation.

The implementation of choosing halal and healthy food attitude needs to be applied by the teachers and must gain significant support from the school. The school can work together with National Agency of Drug and Food Control (BPPOM), Halal Products Certification Agency 
(BPJPH), and Ulama Council of Indonesia (MUI). The implementation of this policy has been successfully implemented in some elementary schools in Semarang, even though there are still some weaknesses [15]. Now is the right time for the school to improve healthy food environment through establishing healthy canteen [8], also develops effective nutrition education for the students like what has been applied in some advance countris and halal awareness [24], [25], supports the habit of tendency in choosing halal and healthy food so that they can grow and develop with good food consumption culture, until it is expected to build smart generation for Indonesia and blessed by Allah SWT.

The circumspection on halal food should be owned by a Muslim since early age. The lack of Muslim elementary schoolstudents' circumspection in consuming halal food is a serious problem which must be the attention of all of us, moreover the parents and teachers. This study ilustrates that students' lack of circumspection towards the halal food needs active roles of all parents andschools. Therefore, all stakeholders included the merchants must be educated well related to the halal of food consumed by kids who are in vulnerable age. It needs cooperation between the university in dedicating their knowledge to educate the parents, merchants around the school, and the school itself. This strategic efforts need to be conducted in order to nurture the health and prevent the risk of disease [2], and to increase the intelligence of elementary school students.

\section{Conclusion}

This research concluded that the majority of muslim students at elementary school in Pekanbaru and around it have food consumption pattern that is not good yet, the selection of food is still not right from the side of health and its halal. The opportunity to improve the quality of food for elementary school students is still adequate. Education towards the students, parents, merchants, and teachers need to be done continuously and followed by evaluation. If necessary, involving the government and private sectors. The other researches related to the danger of consuming unhealthy food and not halal food for students of elementary school in Pekanbaru should be undertaken in order to support this effort.

\section{References}

[1] J. S. Owusu, E. K. Colecraft, R. N. Aryeetey, J. A. Vaccaro, and F. G. Huffman, "Nutrition Intakes and Nutritional Status of School Age Children in Ghana," J. Food Res., vol. 6, no. 2, p. 11, 2017.

[2] N. Iklima, "Gambaran Pemilihan Makanan Jajanan Pada Anak Usia Sekolah Dasar," vol. 5, no. 1, pp. 8-17, 2017.

[3] Alhidayati, A. S. Efendi, and A. Hakim, "FAKTOR-FAKTOR YANG BERHUBUNGAN DENGAN PEMILIHAN MAKANAN JAJANAN SEHAT PADA SISWA THE FACTORS ASSOCIATED WITH THE SELECTION OF HEALTHY SNACKS ON THE STUDENTS OF 145 ELEMENTARY SCHOOL PEKANBARU 2017 Data pengawasan Pangan Jajanan," vol. 1, no. 2, pp. 45-57, 2018.

[4] G. M. Almerico, "Food and Identity: Food Studies, Cultural, and Personal Identity," J. Int. Bus. Cult. Stuedies, vol. 8, pp. 1-7, 2014.

[5] Y. Yasid, F. Farhan, and Y. Andriansyah, "Factors Affecting Muslim Students Awareness of Halal Products in Yogyakarta , Indonesia," vol. 6, pp. 27-31, 2016.

[6] D. Shipman and B. Durmus, "The Effect of Culture on Food Consumption ; a Case of Special Religious Days in Turkey,” vol. 6, no. 2, pp. 92-99, 2017. 
[7] V. Mette and H. Hansen, "The Relationship between Food Preferences and Food Choice: A Theoretical," Int. J. Bus. Soc. Sci., vol. 5, no. 7, pp. 145-157, 2014.

[8] A. Chortatos, L. Terragni, S. Henjum, M. Gjertsen, L. E. Torheim, and M. K. Gebremariam, "Consumption Habits of School Canteen and Non-Canteen Users Among Norwegian Young Adolescents: A Mixed Method Analysis," BMC Pediatr., vol. 18 , no. 1, pp. 1-12, 2018.

[9] V. Sibal, "Food: Identity of culture and religion," Food Cult., vol. JULY-AUG, no. September, pp. 10908-10915, 2018.

[10] A. Tarr, "Food and Culture: From Local Relationality to Global Responsibility," J. Dialogue Cult. , vol. 5, no. 1, pp. 52-62, 2016.

[11] V. Azaïs-braesco, F. Brighenti, R. Paoletti, A. Peracino, and M. Curie, "Healthy food and healthy choices : A new European profile approach \&., vol. 10, pp. 1-11, 2009.

[12] B. Economics and F. Security, "Muslim consumers' awareness and perception of Halal food fraud," vol. 25, no. December, pp. 87-96, 2018.

[13] E. Soesilowati, "Perilaku Konsumsi Muslim dalam Mengkonsumsi Makanan Halal Kasus: Muslim Banten *," 2007, vol. 2006, pp. 1-15.

[14] Y. Mohamed Rahimah, C. Faridah, C. Mahmood, N. Hafizah, and A. Mansor, "Understanding Mechanisms to Promote Halal Industry- The Stakeholders ' Views," Procedia - Soc. Behav. Sci., vol. 130, pp. 160-166, 2014.

[15] H. Mafidayanti and M. Mardiana, "Journal of Health Education," vol. 1, no. 1, pp. 7177, 2016.

[16] H. Jilani et al., "Relative Validity of a Food and Beverage Preference Questionnaire to Characterize Taste Phenotypes in Children Adolescents and Adults," pp. 1-12, 2019.

[17] N. Ramadhani, H. Herlina, and A. J. F. Utama, "Penetapan Kadar Natrium Siklamat Pada Minuman Ringan Kemasan Dengan Menggunakan Metode Spektrofotometri UV," J. Mandala Pharmacon Indones., vol. 4, no. 1, pp. 7-12, 2018.

[18] S. Dian Ardhany and L. Lamsiyah, "TINGKAT PENGETAHUAN PEDAGANG WARUNG TENDA DI JALAN YOS SUDARSO PALANGKARAYATENTANG BAHAYA PENGGUNAAN MINYAK JELANTAH BAGI KESEHATAN," vol. 6, no. 1, pp. 68-72, 2018.

[19] R. dan Marlenywati, "Perilaku Konsumsi Mie Instan Mahasiswa Fakultas Ilmu Kesehatan Universitas Muhammadiyah Dan Jurusan Gizi Poltekkes Kemenkes Pontianak," J. Vokasi Kesehat., vol. Vol 1, pp. 188-194, 2015.

[20] T. D. Ardyanto, "MSG dan Kesehatan: Sejarah, Efek dan Kontroversinya," Inovasi, vol. 1 , no. 16 , pp. 52-56, 2004.

[21] C. T. Ristianingrum, A. D. Moelyaningrum, and R. S. Pujiati, "Higiene Sanitasi dan Zat Pewarna Rhodamin B pada Kue Cenil Studi di Pasar Kecamatan Kota Kabupaten Jember ( Hygiene Sanitation and Rhodamine B Dyes in Cenil Study in Sub-Distric Market, of Jember Distric )," J. Heal. Sci. Prev., vol. 2, no. October, pp. 67-77, 2018.

[22] A. Ika Prastini and S. Bambang Widjanarko, "PEMBUATAN SOSIS AYAM MENGGUNAKAN GEL PORANG (Amorphophallus mueleri Blume) SEBAGAI BAHAN PENGIKAT TERHADAP KARAKTERISTIK SOSIS Production Chicken Sausage Using Porang Gel as a Binder to the Characteristics of Sausages," Pembuatan Sosis Ayam Menggunakan Gel Porang-Prastini, dkk J. Pangan dan Agroindustri, vol. 3, no. 4, pp. 1503-1511, 2015.

[23] O. Meixner, R. Friedl, and B. Hartl, "Preferences for Attributes of Halal Meat: Empirical Evidence from the Muslim Community in Vienna, Austria," pp. 265-278, 2018. 
[24] P. Johnson, D. Gerson, K. Porter, and J. Petrillo, "A Study of School Lunch Food Choice and Consumption among Elementary School Students," Int. J. Child Heal. Nutr., vol. 4, no. 3, pp. 141-150, 2015.

[25] W. Rusni, B. Wan, M. Othman, R. Abdul, and N. Hirawaty, "Halal Malaysia Logo or Brand: The Hidden Gap," Procedia Econ. Financ., vol. 37, no. 16, pp. 254-261, 2016. 